\title{
Dosing Cariprazine Within and Beyond Clinical Trials: Recommendations for the Treatment of Schizophrenia
}

\author{
Elmars Rancans ${ }^{1 *}$, Zsófia Borbála Dombi $^{2,3}$ and Ágota Barabássy ${ }^{2}$ \\ ${ }^{1}$ Department of Psychiatry and Narcology, Riga Stradins University, Riga, Latvia, ${ }^{2}$ Gedeon Richter Plc., Medical Division, \\ Budapest, Hungary, ${ }^{3}$ Department of Psychiatry, University of Oxford, Oxford, United Kingdom
}

Although the optimal dosing of an antipsychotic medication is known to be essential in the long-term management of schizophrenia, in case of novel drugs such as cariprazine, determining the right dosing strategy is not that simple. Without decades of experience with a particular compound, evidence regarding dosing and titration comes primarily from double-blind, placebo controlled clinical trials that are not necessarily mirroring the real-life experiences of doctors. Via summarizing data from both clinical data $(n=3275)$

OPEN ACCESS

Edited by:

Agata Szulc,

Medical University of Warsaw, Poland

Reviewed by:

Andrea Fagiolini,

University of Siena, Italy

Anna Mosiołek,

Klinika Psychiatryczna NOZ

Warszawski Uniwersytet

Medyczny, Poland

*Correspondence:

Elmars Rancans

elmars.rancans@rsu.lv

Specialty section:

This article was submitted to

Psychopharmacology,

a section of the journal

Frontiers in Psychiatry

Received: 03 September 2021

Accepted: 19 November 2021

Published: 05 January 2022

Citation:

Rancans E, Dombi ZB and

Barabássy Á (2022) Dosing

Cariprazine Within and Beyond Clinical

Trials: Recommendations for the

Treatment of Schizophrenia.

Front. Psychiatry 12:770234.

doi: 10.3389/fpsyt.2021.770234 and real-world evidence (observational study $n=116$, case studies $n=29$ ), this perspective paper aims to shed a light on the appropriate dosing strategies of cariprazine from treatment initiation through switching strategies to concomitant medications.

Keywords: cariprazine, schizophrenia, antipsychotic, dosing, psychopharmacotherapy

\section{INTRODUCTION}

Antipsychotic medication, has been prescribed as the first line of treatment in schizophrenia since the 1950s $(1,2)$. While the so-called typical or first-generation antipsychotics (FGAs) such as haloperidol have been associated with considerable side effects, atypical or second-generation antipsychotics (SGAs) changed the view of psychosis treatment by offering similar level of efficacy as FGAs but with much lower rates and severity of adverse events (3). Throughout the past few decades however, third-generation antipsychotics (TGAs), have been in the spotlight given their ability to improve not only positive but potentially negative and cognitive symptoms as well (4-7). Many of these atypical antipsychotics are characterized by dopamine partial agonism (8), which explains their improved efficacy and safety profile (9) but also the fact why practitioners feel challenging to find the right strategy to dose them $(10,11)$.

The optimal dosing of antipsychotics is known to be essential in the long-term management of schizophrenia (12). The general rule is that one should aim for a treatment initiation and titration strategy that promotes quick and adequate response without the introduction of side effects that are too bothersome for the patient (12). Indeed, discontinuation and frequent switching between different antipsychotics due to adverse events or insufficient therapeutic response are highly common in schizophrenia patients $(13,14)$-many practitioners switch or start polypharmacy before optimizing the current medication dose in order to address the patients' complains and to avoid non-adherence (12).

In case of novel drugs however, determining the right dosing strategy is not that simple. Without decades of experience with a particular compound, evidence regarding dosing and titration comes primarily from clinical trials (12). Aiming to determine efficacy against placebo with the lowest 
possible side effects, in such studies manufacturers utilize doses that are often much lower than what is actually needed in real life $(12,15)$. In addition, patients involved in clinical trials are required to fit into a highly rigorous criteria and hence can be immensely different from those seen by doctors in their everyday clinical practice (16). Thus, in this paper, we aim to summarize the clinical data of cariprazine dosing within and beyond clinical trials.

\section{METHODS}

Trials, studies, and cases for this perspective were identified by searching Embase and Medline databases for English language articles published in peer-reviewed journals between 1 January 2000 and 1 June with search terms "(cariprazin* OR "rgh188" OR rgh188) AND ("case report*" OR "case stud"” OR “case series*” OR "trial"” OR "stud")." Searches by hand were also conducted to identify additional relevant articles. Articles were included if they: (1) were an original research conducted with human subjects; (2) involved patients with diagnosis of schizophrenia; (3) provided adequate information regarding the dosing of cariprazine. Out of the 186 findings, 6 clinical trials, 1 observational study and 29 cases met the inclusion criteria.

\section{CARIPRAZINE, A THIRD-GENERATION ANTIPSYCHOTIC AGENT}

Cariprazine is a TGA that is approved for the treatment of schizophrenia by the Food and Drug Administration (FDA) and the European Medicines Agency (EMA). It is a dopamine D3 receptor preferring partial agonist at the D3/D2 and at the serotonin 5-HT1A receptors and an antagonist at the 5-HT2B receptors (17). Compared to other antipsychotics, cariprazine's uniqueness is based in its high potency for the D3 receptor that is higher than what is exhibited by dopamine itself, resulting in full D3 receptor occupancy at clinically relevant doses (17). There are two major active metabolites of cariprazine, namely desmethyl cariprazine (DCAR) and didesmethyl cariprazine (DDCAR) (18, 19). Both are pharmacologically equipotent to cariprazine and are known to be jointly responsible for the overall therapeutic effect $(18,19)$.

Throughout the clinical development programme for the treatment of schizophrenia, the efficacy and safety of cariprazine were established in 8 clinical trials; 4 short-term, randomized, double-blind, placebo-controlled studies with acute patients and 4 long-term studies of various design. In the short-term (6-week) studies patients who had current exacerbation of schizophrenia for $<2$ weeks in duration and were at least moderately ill were included (20-23). Within the 4 long-term studies, there were two 48-week open-label, flexible-dose safety trials, which served as extensions to the short-term studies $(24,25)$. The efficacy of cariprazine for the prevention of relapse in patients with acute schizophrenia was also evaluated in a long-term (up to 97 weeks) trial with a randomized, double-blind, placebo-controlled design (26). Finally, the last clinical trial, a 26-week, double-blind, active-controlled study, measured the efficacy of cariprazine in predominant negative symptoms (7).

Additionally to the clinical trials, there was one observational study in Latvia involving patients who were experiencing predominant negative symptoms despite receiving antipsychotic medication (27). Furthermore, several cases have been published that discuss cariprazine's effectiveness and safety in various schizophrenia patients.

\section{Treatment Initiation With Cariprazine}

Cariprazine is currently approved in four doses: 1.5, 3.0, 4.5, and $6.0 \mathrm{mg} /$ day (28). According to the Summary of Product Characteristics (SmPC) the recommended starting dose for cariprazine is the lowest available dose, $1.5 \mathrm{mg} /$ day $(28,29)$. Indeed, as summarized in Table 1, in the majority of cases cariprazine treatment was initiated with this dose. Exceptions were three patient cases where cariprazine was prescribed in the dose of $3.0 \mathrm{mg} /$ day (40), as well as the Latvian observational study where $7.7 \%$ of patients received $3.0 \mathrm{mg} /$ day, $3.4 \% 6.0 \mathrm{mg} /$ day and $1.7 \% 4.5 \mathrm{mg} /$ day as their starting dose (27). Importantly, as reported in the cases, the higher starting dose was well-tolerated and quick improvement in behavior was detected (40).

After initiation of treatment, cariprazine doses are recommended to be increased in $1.5 \mathrm{mg}$ increments up to a maximum of $6.0 \mathrm{mg} /$ day, if necessary $(28,29)$. In general, there are two main titration strategies - a fast and a slow one. Fast titration involves an increase of $1.5 \mathrm{mg} /$ day each day or every second day until the target dose is achieved, as seen in the short-term clinical trials $(20,21,23)$. This or similar strategy was utilized in several cases $(31,33-35,37,40,41,43)$, where $3.0 \mathrm{mg} /$ day dose was introduced within less than a week after the beginning of the treatment. In these cases, most of the patients exhibited considerable psychotic symptoms with or without negative symptoms and weight gain problems caused by previous medication. The other-slow-titration strategy has been described in one of the long-term studies, where patients with predominant negative symptoms received cariprazine in a dose of $1.5 \mathrm{mg}$ /day until week 1 and then doses were increased in $1.5 \mathrm{mg}$ increments weekly up until $6.0 \mathrm{mg} / \mathrm{day}$, if it was needed (7). It is also worth to note however, that in this study cross-titration with previous antipsychotic medication was performed in the first two weeks of treatment, whereas in the short-term studies a 7-day wash-out period before cariprazine monotherapy was introduced (20-23). Slow titration strategy was also performed in cases where patients were less psychotic $(30,39)$ or received cariprazine as add-on treatment $(32,36)$. As expected, in the Latvian observational study both strategies were present (27); in $34 \%$ of the patients, dose was increased every $3 \mathrm{rd}$ day, in $28 \%$ every 4 th day, in $6 \%$ every 6 th day and in $32 \%$ every 7 th day.

\section{Switching From Another Antipsychotic to Cariprazine}

In case of cariprazine, switching from another antipsychotic can be beneficial if there has been no or only partial response to positive or negative symptoms $(27,31,32,35,37,41$, $43)$, if the patient suffers from side effects $(27,34-36,42)$ 
TABLE 1 | Dosing strategies with cariprazine.

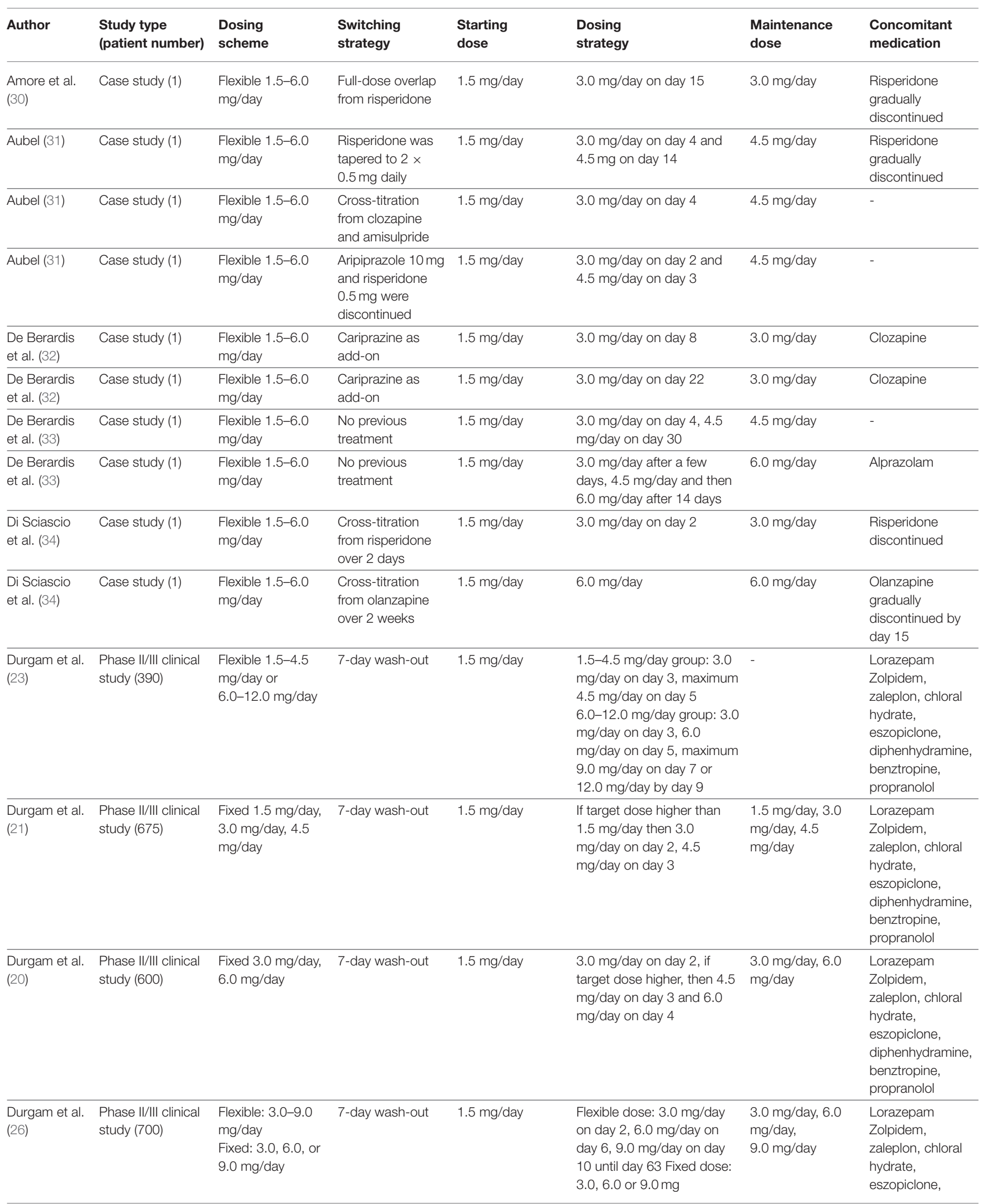


TABLE 1 | Continued

\begin{tabular}{|c|c|c|c|c|c|c|c|}
\hline Author & $\begin{array}{l}\text { Study type } \\
\text { (patient number) }\end{array}$ & $\begin{array}{l}\text { Dosing } \\
\text { scheme }\end{array}$ & $\begin{array}{l}\text { Switching } \\
\text { strategy }\end{array}$ & $\begin{array}{l}\text { Starting } \\
\text { dose }\end{array}$ & $\begin{array}{l}\text { Dosing } \\
\text { strategy }\end{array}$ & $\begin{array}{l}\text { Maintenance } \\
\text { dose }\end{array}$ & $\begin{array}{l}\text { Concomitant } \\
\text { medication }\end{array}$ \\
\hline & & & & & $\begin{array}{l}\text { between day } 63 \text { to } 147 \\
\text { Fixed-dose double blind: } \\
\text { randomized to } 3.0 .6 .0 \text { or } \\
9.0 \mathrm{mg} \text { between day } 147 \\
\text { to } 644\end{array}$ & & $\begin{array}{l}\text { diphenhydramine, } \\
\text { benztropine, } \\
\text { propranolol }\end{array}$ \\
\hline $\begin{array}{l}\text { Heck et al. } \\
\text { (36) }\end{array}$ & Case study (1) & $\begin{array}{l}\text { Flexible 1.5-6.0 } \\
\mathrm{mg} / \text { day }\end{array}$ & $\begin{array}{l}\text { Discontinuation of } \\
\text { quetiapine before } \\
\text { start of } \\
\text { cariprazine, then } \\
\text { adding quetiapine } \\
\text { again }\end{array}$ & $1.5 \mathrm{mg} /$ day & $3.0 \mathrm{mg} /$ day on day 5 & $\begin{array}{l}\text { Cariprazine was } \\
\text { reduced to } 1.5 \\
\mathrm{mg} / \text { day } \\
3 \text { days after the } \\
\text { onset of akathisia. } \\
\text { Another } 2 \text { days } \\
\text { later, cariprazine } \\
\text { was stopped. }\end{array}$ & Quetiapine \\
\hline $\begin{array}{l}\text { Heck et al. } \\
\text { (36) }\end{array}$ & Case study (1) & $\begin{array}{l}\text { Flexible 1.5-6.0 } \\
\mathrm{mg} / \text { day }\end{array}$ & $\begin{array}{l}\text { Cariprazine as } \\
\text { add-on }\end{array}$ & $1.5 \mathrm{mg} /$ day & $3.0 \mathrm{mg} /$ day on day 15 & $\begin{array}{l}\text { Developed severe } \\
\text { Parkinsonism, } \\
\text { risperidone } \\
\text { treatment was fully } \\
\text { stopped, } 1.5 \\
\text { mg/day } \\
\text { cariprazine was } \\
\text { maintained }\end{array}$ & $\begin{array}{l}\text { Risperidone and } \\
\text { biperiden }\end{array}$ \\
\hline $\begin{array}{l}\text { Heck et al. } \\
\text { (36) }\end{array}$ & Case study (1) & $\begin{array}{l}\text { Flexible 1.5-6.0 } \\
\mathrm{mg} / \text { day }\end{array}$ & $\begin{array}{l}\text { No previous } \\
\text { treatment }\end{array}$ & $1.5 \mathrm{mg} / \mathrm{day}$ & $\begin{array}{l}3.0 \mathrm{mg} / \text { day on day } 8,4.5 \\
\mathrm{mg} / \text { day on day } 13\end{array}$ & $4.5 \mathrm{mg} / \mathrm{day}$ & $\begin{array}{l}\text { Pipamperone, } \\
\text { then olanzapine }\end{array}$ \\
\hline $\begin{array}{l}\text { Heck et al. } \\
\text { (36) }\end{array}$ & Case study (1) & $\begin{array}{l}\text { Flexible } 1.5-6.0 \\
\mathrm{mg} / \text { day }\end{array}$ & $\begin{array}{l}\text { Cross-titration } \\
\text { from amisulpride }\end{array}$ & $1.5 \mathrm{mg} /$ day & $\begin{array}{l}3.0 \mathrm{mg} / \text { day on day } 15,4.5 \\
\mathrm{mg} / \text { day on day } 29 \text {, and } 6.0 \\
\mathrm{mg} / \text { day on day } 85\end{array}$ & $6.0 \mathrm{mg} / \mathrm{day}$ & - \\
\hline $\begin{array}{l}\text { Kapulsky } \\
\text { et al. (37) }\end{array}$ & Case study (1) & $\begin{array}{l}\text { Flexible } 1.5-6.0 \\
\mathrm{mg} / \text { day }\end{array}$ & $\begin{array}{l}\text { Abrupt } \\
\text { discontinuation of } \\
\text { clozapine and } \\
\text { gradual titration of } \\
\text { cariprazine }\end{array}$ & - & $6.0 \mathrm{mg} /$ day by day 7 & $\begin{array}{l}\text { Discontinued due } \\
\text { to urinary retention }\end{array}$ & - \\
\hline $\begin{array}{l}\text { Mencacci } \\
\text { et al. (38) }\end{array}$ & Case study (1) & $\begin{array}{l}\text { Flexible } 1.5-6.0 \\
\mathrm{mg} / \text { day }\end{array}$ & $\begin{array}{l}\text { Cross-titration } \\
\text { from haloperidol } \\
\text { and risperidone } \\
\text { over } 1 \text { month }\end{array}$ & - & up to $4.5 \mathrm{mg} /$ day & $4.5 \mathrm{mg} / \mathrm{day}$ & $\begin{array}{l}\text { Haloperidol and } \\
\text { risperidone } \\
\text { gradually } \\
\text { discontinued }\end{array}$ \\
\hline $\begin{array}{l}\text { Mencacci } \\
\text { et al. (38) }\end{array}$ & Case study (1) & $\begin{array}{l}\text { Flexible 1.5-6.0 } \\
\mathrm{mg} / \text { day }\end{array}$ & $\begin{array}{l}\text { Cross-titration } \\
\text { from olanzapine } \\
\text { over } 3 \text { weeks }\end{array}$ & - & $\begin{array}{l}\text { up to } 4.5 \mathrm{mg} / \text { day until day } \\
21\end{array}$ & $4.5 \mathrm{mg} / \mathrm{day}$ & $\begin{array}{l}\text { Olanzapine } \\
\text { gradually } \\
\text { discontinued, } \\
\text { biperiden, } \\
\text { lorazepam, } \\
\text { antihistamine }\end{array}$ \\
\hline $\begin{array}{l}\text { Molnar et al. } \\
\text { (39) }\end{array}$ & Case study (1) & $\begin{array}{l}\text { Flexible 1.5-6.0 } \\
\text { mg/day }\end{array}$ & $\begin{array}{l}\text { No previous } \\
\text { treatment }\end{array}$ & $1.5 \mathrm{mg} /$ day & $\begin{array}{l}\text { up to } 4.5 \mathrm{mg} / \text { day until day } \\
14\end{array}$ & $3.0 \mathrm{mg} / \mathrm{day}$ & - \\
\hline
\end{tabular}


TABLE 1 | Continued

\begin{tabular}{|c|c|c|c|c|c|c|c|}
\hline Author & $\begin{array}{l}\text { Study type } \\
\text { (patient number) }\end{array}$ & $\begin{array}{l}\text { Dosing } \\
\text { scheme }\end{array}$ & $\begin{array}{l}\text { Switching } \\
\text { strategy }\end{array}$ & $\begin{array}{l}\text { Starting } \\
\text { dose }\end{array}$ & $\begin{array}{l}\text { Dosing } \\
\text { strategy }\end{array}$ & $\begin{array}{l}\text { Maintenance } \\
\text { dose }\end{array}$ & $\begin{array}{l}\text { Concomitant } \\
\text { medication }\end{array}$ \\
\hline $\begin{array}{l}\text { Montes et al. } \\
(40)\end{array}$ & Case study (1) & $\begin{array}{l}\text { Flexible 1.5-6.0 } \\
\text { mg/day }\end{array}$ & $\begin{array}{l}\text { No previous } \\
\text { treatment }\end{array}$ & $3.0 \mathrm{mg} /$ day & - & 3.0 mg/day & - \\
\hline $\begin{array}{l}\text { Montes et al. } \\
(40)\end{array}$ & Case study (1) & $\begin{array}{l}\text { Flexible 1.5-6.0 } \\
\text { mg/day }\end{array}$ & $\begin{array}{l}\text { No previous } \\
\text { treatment }\end{array}$ & 3.0 mg/day & 6.0 mg/day on day 3 & $6.0 \mathrm{mg} / \mathrm{day}$ & Diazepam \\
\hline $\begin{array}{l}\text { Montes et al. } \\
(40)\end{array}$ & Case study (1) & $\begin{array}{l}\text { Flexible 1.5-6.0 } \\
\text { mg/day }\end{array}$ & $\begin{array}{l}\text { Abrupt } \\
\text { discontinuation of } \\
\text { aripiprazole }\end{array}$ & 3.0 mg/day & $6.0 \mathrm{mg} /$ day on day 3 & $6.0 \mathrm{mg} /$ day & Quetiapine \\
\hline $\begin{array}{l}\text { Müller et al. } \\
(41)\end{array}$ & Case study (1) & $\begin{array}{l}\text { Flexible 1.5-6.0 } \\
\text { mg/day }\end{array}$ & $\begin{array}{l}\text { Quetiapine and } \\
\text { amisulpride } \\
\text { wash-out phase } \\
\text { over } 4 \text { days }\end{array}$ & 1.5 mg/day & $\begin{array}{l}3.0 \text { mg/day on day } 5,4.5 \\
\text { mg/day on day } 13\end{array}$ & 4.5 mg/day & - \\
\hline $\begin{array}{l}\text { Müller et al. } \\
(41)\end{array}$ & Case study (1) & $\begin{array}{l}\text { Flexible 1.5-6.0 } \\
\text { mg/day }\end{array}$ & $\begin{array}{l}\text { Cross-titration } \\
\text { from olanzapine } \\
\text { over } 3 \text { days and } \\
\text { risperidone over } \\
10 \text { days }\end{array}$ & 1.5 mg/day & $\begin{array}{l}3.0 \text { mg/day on day } 3,4.5 \\
\text { mg/day on day } 24\end{array}$ & 4.5 mg/day & $\begin{array}{l}\text { Risperidone until } \\
4.5 \text { mg cariprazine }\end{array}$ \\
\hline $\begin{array}{l}\text { Németh et al. } \\
\text { (7) }\end{array}$ & $\begin{array}{l}\text { Phase II/III clinical } \\
\text { study (460) }\end{array}$ & $\begin{array}{l}\text { Flexible: } 3.0-6.0 \\
\text { mg/day }\end{array}$ & $\begin{array}{l}\text { Cross-titration } \\
\text { over } 2 \text { weeks }\end{array}$ & 1.5 mg/day & $\begin{array}{l}3.0 \mathrm{mg} / \text { day on day } 7-13 \\
4.5 \mathrm{mg} / \text { day on day } 14\end{array}$ & $\begin{array}{l}3.0 \mathrm{mg} / \text { day, } 4.5 \\
\mathrm{mg} / \mathrm{day} \\
6.0 \mathrm{mg} / \text { day }\end{array}$ & $\begin{array}{l}\text { Trihexyphenidyl } \\
\text { Hydrochloride, } \\
\text { biperiden, } \\
\text { propranolol }\end{array}$ \\
\hline $\begin{array}{l}\text { Rancans } \\
\text { et al. ( } 27)\end{array}$ & $\begin{array}{l}\text { Observational } \\
\text { study (116) }\end{array}$ & $\begin{array}{l}\text { Flexible 1.5-6.0 } \\
\text { mg/day }\end{array}$ & $\begin{array}{l}\text { Cross-titration } \\
\text { over } 2 \text { weeks }\end{array}$ & $\begin{array}{l}1.5,3.0,4.5,6.0 \\
\text { mg/day }\end{array}$ & Cross-titration until day 14 & $\begin{array}{l}1.5 \text { mg/day, } 3.0 \\
\text { mg/day, } 4.5 \\
\text { mg/day, } 6.0 \\
\text { mg/day } \\
7.5 \text { mg/day }\end{array}$ & $\begin{array}{l}\text { Anti-EPS } \\
\text { medication, } \\
\text { antidepressants, } \\
\text { benzodiazepines, } \\
\text { mood stabilizers }\end{array}$ \\
\hline $\begin{array}{l}\text { Riedesser } \\
\text { et al. (42) }\end{array}$ & Case study (1) & $\begin{array}{l}\text { Flexible 1.5-6.0 } \\
\text { mg/day }\end{array}$ & $\begin{array}{l}\text { Cariprazine as } \\
\text { add-on }\end{array}$ & $1.5 \mathrm{mg} /$ day & Discontinued after 6 days & - & $\begin{array}{l}\text { Clozapine, } \\
\text { escitalopram }\end{array}$ \\
\hline $\begin{array}{l}\text { Riedesser } \\
\text { et al. (42) }\end{array}$ & Case study (1) & $\begin{array}{l}\text { Flexible 1.5-6.0 } \\
\text { mg/day }\end{array}$ & $\begin{array}{l}\text { Cariprazine as } \\
\text { add-on }\end{array}$ & 1.5 mg/day & $4.5 \mathrm{mg} /$ day & 3.0 mg/day & $\begin{array}{l}\text { Amisulpride, } \\
\text { hydro- } \\
\text { chlorothiazide, } \\
\text { amlodipine and } \\
\text { ramipril }\end{array}$ \\
\hline $\begin{array}{l}\text { Riedesser } \\
\text { et al. (42) }\end{array}$ & Case study (1) & $\begin{array}{l}\text { Flexible 1.5-6.0 } \\
\text { mg/day }\end{array}$ & $\begin{array}{l}\text { Abrupt } \\
\text { discontinuation of } \\
\text { risperidone and } \\
\text { olanzapine } 4 \text { days } \\
\text { later }\end{array}$ & $1.5 \mathrm{mg} /$ day & $3.0 \mathrm{mg} /$ day & $\begin{array}{l}\text { Discontinued after } \\
14 \text { days }\end{array}$ & Pantoprazole \\
\hline Vita et al. (43) & Case study (1) & $\begin{array}{l}\text { Flexible 1.5-6.0 } \\
\text { mg/day }\end{array}$ & $\begin{array}{l}\text { Cross-titration } \\
\text { from risperidone } \\
\text { over } 9 \text { day }\end{array}$ & $1.5 \mathrm{mg} / \mathrm{day}$ & $\begin{array}{l}3.0 \mathrm{mg} / \text { day on day } 4,4.5 \\
\mathrm{mg} / \text { day on day } 8\end{array}$ & $4.5 \mathrm{mg} / \mathrm{day}$ & $\begin{array}{l}\text { Risperidone } \\
\text { discontinued }\end{array}$ \\
\hline Vita et al. (43) & Case study (1) & $\begin{array}{l}\text { Flexible 1.5-6.0 } \\
\text { mg/day }\end{array}$ & $\begin{array}{l}\text { Abrupt-gradual } \\
\text { from paliperidone } \\
\text { long-acting }\end{array}$ & $1.5 \mathrm{mg} / \mathrm{day}$ & $\begin{array}{l}3.0 \mathrm{mg} / \text { day on day } 4,4.5 \\
\text { mg/day on day } 8,6.0 \\
\text { mg/day on day } 12\end{array}$ & 6.0 mg/day & $\begin{array}{l}\text { Paliperidone } \\
\text { discontinued }\end{array}$ \\
\hline
\end{tabular}

that are less common with cariprazine such as weight gain, hyperprolactinemia, sexual disturbance or sedation (44) or if the patients has been prone to non-adherence or substance abuse $(29,35)$.

In general, there are four possible ways of switching antipsychotics; abrupt, abrupt-gradual, gradual-gradual (i.e., cross-tapering) and gradual-abrupt $(12,29)$. In case of abrupt switching, the previous antipsychotics medication is promptly discontinued, while the new one is immediately started $(12,29)$. The second option is to immediately discontinue the current medication and gradually introducing the new one (abruptgradual) $(12,29)$. In contrast to this option, gradual-abrupt switching involves the gradual dose reduction of the previous medication and the immediate start of the new one $(12,29)$. Finally, in cross-tapering the new antipsychotic is gradually introduced while the previous is gradually tapered down $(12,29)$. This can be achieved in two ways as well, either at the same time, or delayed; first, reaching a plateau where the target dose of the new antipsychotic is achieved and only then starting to decrease the dose of the previous medication (full-dose overlap) (12).

The most recommended strategy for switching to cariprazine is gradual cross-titration with different timeframes depending on the mechanism of action of the previous medication as seen in Figure $1(29,48)$. In case of antipsychotics that have 


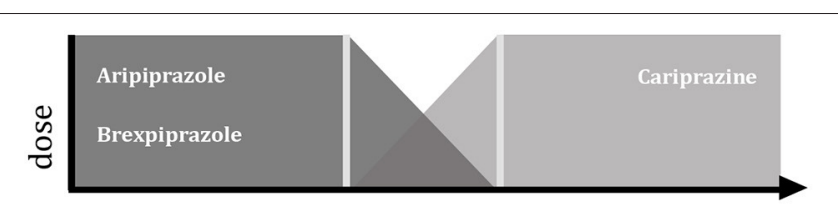

1 WEEK

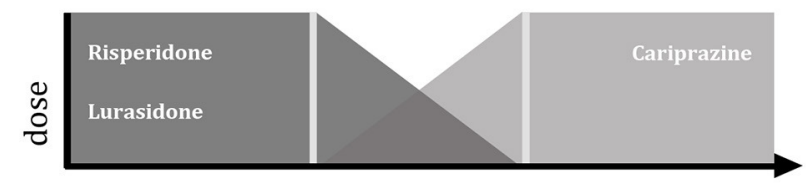

2 WEEKS

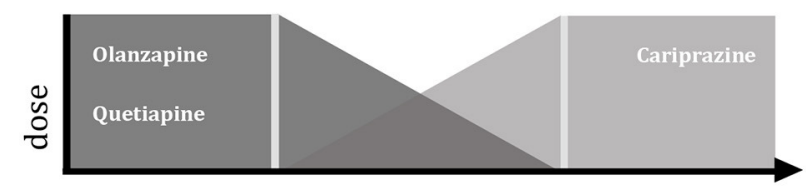

3 WEEKS
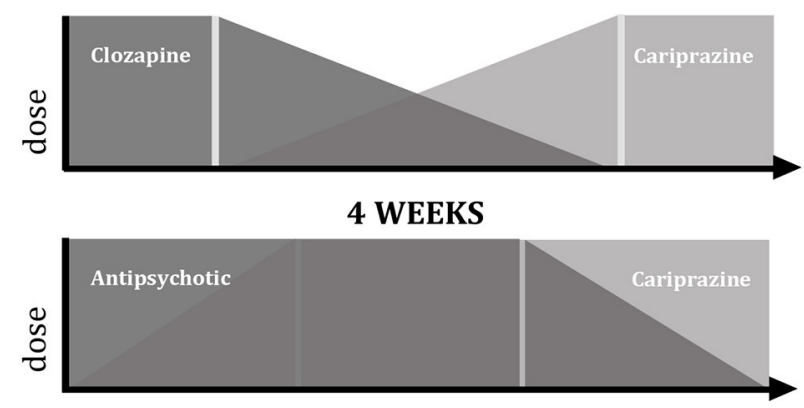

FULL-DOSE OVERLAP

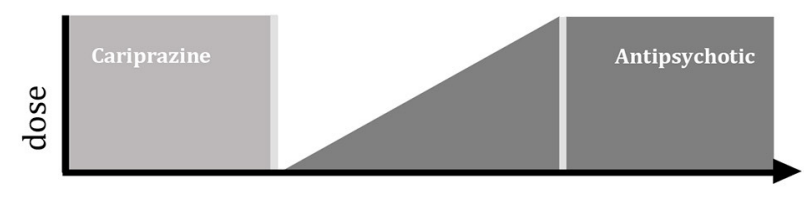

3 WEEKS

FIGURE 1 | Switching strategies with cariprazine. Graphic representation of data according to Németh et al. (7), Fagiolini et al. (45), Sullivan et al. (46), Stephen (47).

a similar profile to cariprazine i.e., partial agonism at the D2 receptor with comparable histaminergic and cholinergic affinity (e.g., aripiprazole), a 1-week cross-titration is recommended where the previous drug is tapered off within 7 days while at the same time cariprazine dose is escalated to the target dose $(29,48)$. In contrast, about 2 weeks is necessary if switching from a second-generation antipsychotic that has D2 antagonism (e.g., risperidone) in order to avoid dopaminergic rebound causing increased psychotic symptoms, agitation and dyskinesia (29, 48). Finally, most time (3-4 weeks) should be given when switching from antipsychotics with completely different receptor profiles i.e., those with stronger antihistaminic and/or anticholinergic affinity (e.g., olanzapine, quetiapine or clozapine) so that histaminergic and cholinergic rebound is avoided hence reducing the risk of insomnia, nausea and vomiting $(29,48)$. At last, various panels emphasize the advantages of a full-dose overlap when switching to cariprazine regardless of the type of antipsychotic drug that has been taken by the patient $(45,46)$. In such case, a period of overlap for about 2 weeks is recommended before the tapering down of the previous medication hence ensuring that there will be no relapse of symptoms $(45,46)$.

When analyzing data from clinical cases however, the picture regarding switching strategies is much more mixed. In case of switching from risperidone, some chose abrupt switching (42), while others discontinued it over 2, 9 or 10 days period while gradually increasing the dose of cariprazine $(34,41,43)$. Similarly, abrupt stop as well as cross-titration over a 3-day, 2- or 3week period was described when switching from olanzapine to cariprazine $(34,38,41)$. Interestingly, abrupt switching was frequently described in case of quetiapine $(36,41)$ and clozapine as well (37). In case of making the clinical decision to switch from cariprazine to another antipsychotic, the abrupt-gradual strategy is recommended due to the long half-life of cariprazine (28).

Even if carefully planned and executed however, complications throughout switching can still emerge. In case of a dopaminergic rebound, the re-initiation or dose increase of the previous antipsychotic is recommended (29). If appropriate, this strategy can also be applied to cholinergic and histaminergic rebounds, however in general, the adding of an anticholinergic (e.g., biperiden) or antihistamine (e.g., hydroxyzine) medication can also solve the complications (29). One of the most common side effects of antipsychotic medications is akathisia which can also emerge during a switching period and is recommended to be managed with beta-blockers (e.g., propranolol), benzodiazepines or anticholinergics (29).

\section{Maintenance Treatment and Concomitant Medications}

Maintenance treatment involves the stabilization of the patient on a certain dose that has the ability to control the patient's symptoms without causing any side effects that are intolerable for the patient. Among the four available doses of cariprazine, all doses can be utilized as maintenance dose-depending on the patient's symptom and side effect profile. For instance, although the $1.5 \mathrm{mg} /$ day is most often prescribed in the treatment initiation phase, $11 \%$ of the patients in the Latvian study and $4 \%$ of the reviewed cases remained on it long-term. Importantly, the rest of the doses were used as maintenance dose equally in these real-life settings; about one fourth of the patients were on 3.0 $\mathrm{mg} /$ day, one fourth on $4.5 \mathrm{mg} /$ day and another one fourth on $6.0 \mathrm{mg} /$ day. These data also shows that patients stabilizing on $6.0 \mathrm{mg} /$ day are more usually psychotic and hence require higher D2 activity, while the lower doses found to be more adequate for improving negative and cognitive symptoms. If looking at the pooled data of the fixed-dose studies, based on the effect sizes for the PANSS total and positive symptom factor scores, the optimal dose for most schizophrenia patients is the 4.5 $\mathrm{mg} /$ day (49). Thus, prescribing this dose for an adequate time is recommended before switching from cariprazine to another antipsychotic medication due to insufficient effectiveness.

Additionally, the final dose of cariprazine is often related to the maintenance dose of the previous antipsychotic medication 
(29). Equivalent doses of different antipsychotics are clearly described in The Maudsley Prescribing Guidelines in Psychiatry (50) where it has been stated that $3 \mathrm{mg}$ cariprazine is approximately the same dose as $3 \mathrm{mg}$ risperidone, $10 \mathrm{mg}$ olanzapine, $80 \mathrm{mg}$ lurasidone, $2 \mathrm{mg}$ brexpiprazole, $300 \mathrm{mg}$ quetiapine and $400 \mathrm{mg}$ amisulpride. Indeed, in the negative symptom study, patients were randomized to receive fixed doses of cariprazine ( $3 \mathrm{mg}, 4.5 \mathrm{mg}$ or $6 \mathrm{mg}$ per day) or the equivalent in risperidone (3 mg, $4.0 \mathrm{mg}$ or $6 \mathrm{mg}$ per day) (7). Additionally, the same principle was applied in a case by Di Sciascio et al. that reported a successful switch and maintenance from risperidone $3 \mathrm{mg}$ to cariprazine $3 \mathrm{mg}$ per day (34).

Even though cariprazine is approved for mono-therapeutic use, polypharmacy-essentially the use of more medicationsis quite common in real-life settings $(51,52)$. In fact, in 5 out of the 29 cases was cariprazine used as an add-on treatment $(32,36,42)$. To give an example, De Berardis and colleagues utilized cariprazine successfully in combination with clozapine in two patients and reported the effects of cariprazine combination to be remarkable not only regarding symptom control but also concerning the management of side effects caused by clozapine (32). Moreover, in the Latvian observational study, $27 \%$ of patients were taking quetiapine, $10 \%$ olanzapine and $9 \%$ clozapine at their last visit, mostly for non-specific sedation or control of anxiety (27). Importantly, in a post-hoc analysis of the cross-titration period of the negative symptom study (7), the co-administration of cariprazine with other antipsychotic medications did not show an unexpected safety profile nor overlapping toxicities, suggesting that it is unlikely that safety will be compromised if polypharmacy with cariprazine is unavoidable (53). This shows that in certain cases patients can benefit from cariprazine combination treatment, nonetheless only if the second antipsychotic is well-chosen with careful consideration regarding the compatibility of the two medications (54).

Concomitant medications other than antipsychotics are well-described in the cariprazine literature. In the clinical trials zolpidem, zaleplon, chloral hydrate, or eszopiclone for insomnia, diphenhydramine, benztropine, or propranolol as rescue medication for extrapyramidal (EPS) symptoms, and lorazepam for agitation, restlessness, irritability, and hostility were permitted $(20,21,23,26)$. Similarly, in the Latvian observational study anti-EPS medication, benzodiazepines, mood stabilizers and antidepressants were allowed (27). Nonetheless, it is important to note that fewer patients needed concomitant medication with cariprazine compared to the antipsychotic they were previously on; $14 \%$ of the patients stopped taking anti-EPS medication, 5\% antidepressants and mood stabilizers and 3\% benzodiazepines (27). In the reviewed cases, most concomitant medications were benzodiazepines (alprazolam, lorazepam and diazepam) $(33,35,38,40)$ and biperiden $(36,38)$.

\section{DISCUSSION}

The success of antipsychotic treatment depends not only on the mechanism of action of a compound but also on the physician's ability to find the right dosing strategy in which the medication is introduced to the patient. This is especially important, as high levels of non-adherence is caused by issues with ineffectiveness and adverse drug reactions which in turn can increase the risk of relapse $(55,56)$. With years of practice with a certain antipsychotic medication, clinicians can make confident decisions on how to switch from one medication to another, but this is more complicated with a novel compound such as cariprazine where most data is coming from clinical trials where the conditions are often different from what is seen in real-life practice.

Based on the reviewed literature, it can be stated that evidence regarding dosing, titration and switching strategies with cariprazine is not that different from trials compared to real-life settings. Almost all patients outside of clinical trials received 1.5 $\mathrm{mg} /$ day as their first dose of cariprazine, as recommended by the SmPC, however those who started with higher doses tolerated cariprazine just as well and reported effectiveness soon after the beginning of treatment. Higher initial doses might work if they are the corresponding dose of the previous medication or if they are at least half of the target dose.

More variance was found in how cariprazine was up-titrated; compared to the $1.5 \mathrm{mg}$ increase a day or every second day, the dose of cariprazine was increased every third or fourth day, depending on the down-titration of the outgoing antipsychotic medication. Importantly, quicker up-titration was utilized when patients were not switching from another medication but were drug-free or acutely ill with mostly psychotic symptoms. In contrast, slower titration strategies seem to work for patients with more negative symptoms better.

Cross-titration strategies from antipsychotics with different receptor profiles and mechanism of action were also reviewed in detail and evidence shows that gradual switching where the dose of the outgoing antipsychotic is continuously decreased while cariprazine dose is increased is the safest option, as with this strategy the risk of rebounds and adverse reaction are the lowest. The timeframe of the cross-titration should depend on the previous medication; the more similar to cariprazine, the less time is needed. In case of the emergence of any side effects such as anxiety or agitation during the cross-titration period, three options are present-decreasing the dose of cariprazine, slowing down the titration process or control with additional medication such as benzodiazepines or quetiapine.

After the cross-titration period, maintenance treatment follows where patients were found to receive $3.0 \mathrm{mg}, 4.5 \mathrm{mg}$, and $6.0 \mathrm{mg}$ per day equally often in real-life settings. However, when analyzing the clinical data, $4.5 \mathrm{mg}$ /day was reported as the most appropriate dose. Although recommended as monotherapy, cariprazine was also found to be effective in combination with other medications such as clozapine. If polypharmacy is unavoidable however, the compatibility of the drugs in terms of receptor affinity and mechanism of action should be evaluated.

\section{DATA AVAILABILITY STATEMENT}

Data presented in the article can be found in already published materials that are cited accordingly. 
Further questions should be directed to the corresponding author.

\section{AUTHOR CONTRIBUTIONS}

$\mathrm{ER}, \mathrm{ZBD}$, and $\mathrm{AB}$ contributed to the conception of the manuscript. ZBD wrote the first draft of the manuscript. All

\section{REFERENCES}

1. Mossman D, Lehrer DS. Conventional and atypical antipsychotics and the evolving standard of care. Psychiatr Serv. (2000) 51:1528-35. doi: 10.1176/appi.ps.51.12.1528

2. Goff DC, Falkai P, Fleischhacker WW, Girgis RR, Kahn RM, Uchida $\mathrm{H}$, et al. The long-term effects of antipsychotic medication on clinical course in schizophrenia. Am J Psychiatry. (2017) 174:840-9. doi: 10.1176/appi.ajp.2017.16091016

3. Solmi M, Murru A, Pacchiarotti I, Undurraga J, Veronese N, Fornaro M, et al. Safety, tolerability, and risks associated with first-and second-generation antipsychotics: A state-of-the-art clinical review. Ther Clin Risk Manag. (2017) 13:757-77. doi: 10.2147/TCRM.S117321

4. Orsolini L, De Berardis D, Volpe U. Up-to-date expert opinion on the safety of recently developed antipsychotics. Expert Opin Drug Saf. (2020) 19:981-98. doi: 10.1080/14740338.2020.1795126

5. Limandri BJ. Clinical use of dopamine modulators as third-generation antipsychotic agents. J Psychosoc Nurs Ment Health Serv. (2019) 57:711. doi: 10.3928/02793695-20190116-02

6. Fleischhacker W, Galderisi S, Laszlovszky I, Szatmári B, Barabássy Á, Acsai $\mathrm{K}$, et al. The efficacy of cariprazine in negative symptoms of schizophrenia: post hoc analyses of PANSS individual items and PANSS-derived factors. Eur Psychiatry. (2019) 58:1-9. doi: 10.1016/j.eurpsy.2019.01.015

7. Németh G, Laszlovszky I, Czobor P, Szalai E, Szatmári B, Harsányi $\mathrm{J}$, et al. Cariprazine versus risperidone monotherapy for treatment of predominant negative symptoms in patients with schizophrenia: a randomised, double-blind, controlled trial. Lancet. (2017) 389:1103-13. doi: 10.1016/S0140-6736(17)30060-0

8. Mauri MC, Paletta S, Maffini M, Colasanti A, Dragogna F, Di Pace C, et al. Clinical pharmacology of atypical antipsychotics: an update. EXCLI J. (2014) 13:1163-91.

9. Ohlsen RI, Pilowsky LS. The place of partial agonism in psychiatry: recent developments. J Psychopharmacol. (2005) 19:408-13. doi: 10.1177/0269881105053308

10. Schwartz TL, Stahl SM. Treatment strategies for dosing the second generation antipsychotics. CNS Neurosci Ther. (2011) 17:110-7. doi: 10.1111/j.1755-5949.2011.00234.x

11. Citrome L, Jaffe A, Levine J. Datapoints: The ups and downs of dosing second-generation antipsychotics. Psychiatr Serv. (2007) 58:11. doi: 10.1176/ps.2007.58.1.11

12. Buckley PF, Correll CU. Strategies for dosing and switching antipsychotics for optimal clinical management. J Clin Psychiatry. (2008) 69:4-17.

13. Fleischhacker WW, Oehl MA, Hummer M. Factors influencing compliance in schizophrenia patients. J Clin Psychiatry. (2003) 64:10-3.

14. Velligan DI, Weiden PJ, Sajatovic M, Scott J, Carpenter D, Ross R. The expert consensus guideline series: Adherence problems in patients with serious and persistent mental illness. J Clin Psychiatry. (2009) 70:146. doi: 10.4088/JCP.7090sulcj

15. Owen RR, Fischer EP, Kirchner JAE, Thrush CR, Williams DK, Cuffel BJ, et al. Clinical practice variations in prescribing antipsychotics for patients with schizophrenia. Am J Med Qual. (2003) 18:140-6. doi: 10.1177/106286060301800402

16. Preskorn SH. Relating clinical trials to psychiatric practice: part II: the gap between the usual patient in registration trials and in practice. $J$ Psychiatr Pract. (2003) 9:455-61. doi: 10.1097/00131746-200311000-00008 authors contributed to manuscript revision, read, and approved the submitted version.

\section{FUNDING}

Gedeon Richter Plc. provided funds for the open access publication fees. The funder had no further input in the preparation of this article.
17. Calabrese F, Tarazi FI, Racagni G, Riva MA. The role of dopamine D 3 receptors in the mechanism of action of cariprazine. CNS Spectr. (2020) 25:343-51. doi: 10.1017/S109285291900083X

18. Kiss B, Némethy Z, Fazekas K, Kurkó D, Gyertyán I, Sághy K, et al. Preclinical pharmacodynamic and pharmacokinetic characterization of the major metabolites of cariprazine. Drug Des Devel Ther. (2019) 13:322948. doi: 10.2147/DDDT.S188760

19. Nakamura T, Kubota T, Iwakaji A, Imada M, Kapás M, Morio Y. Clinical pharmacology study of cariprazine (MP-214) in patients with schizophrenia (12-week treatment). Drug Des Devel Ther. (2016) 10:32738. doi: 10.2147/DDDT.S95100

20. Durgam S, Cutler AJ, Lu K, Migliore R, Ruth A, Laszlovszky I, et al. Cariprazine in acute exacerbation of schizophrenia: a fixed-dose, phase 3, randomized, double-blind, placebo- and active-controlled trial. J Clin Psychiatry. (2015) 76:e1574-82. doi: 10.4088/JCP. $15 \mathrm{~m} 09997$

21. Durgam S, Starace A, Li D, Migliore R, Ruth A, Németh G, et al. An evaluation of the safety and efficacy of cariprazine in patients with acute exacerbation of schizophrenia: a phase II, randomized clinical trial. Schizophr Res. (2014) 152:450-7. doi: 10.1016/j.schres.2013. 11.041

22. Kane JM, Zukin S, Wang Y, Lu K, Ruth A, Nagy K, et al. Efficacy and safety of cariprazine in acute exacerbation of schizophrenia: results from an international, phase iii clinical trial. J Clin Psychopharmacol. (2015) 35:36773. doi: 10.1097/JCP.0000000000000346

23. Durgam S, Litman RE, Papadakis K, Li D, Németh G, Laszlovszky I. Cariprazine in the treatment of schizophrenia: a proof-of-concept trial. Int Clin Psychopharmacol. (2016) 2:61-8. doi: 10.1097/YIC.0000000000000110

24. Cutler AJ, Durgam S, Wang Y, Migliore R, Lu K, Laszlovszky I, et al. Evaluation of the long-term safety and tolerability of cariprazine in patients with schizophrenia: Results from a 1-year open-label study. CNS Spectr. (2018) 23:39-50. doi: 10.1017/S1092852917000220

25. Durgam S, Greenberg WM Li D, Lu K, Laszlovszky I, Nemeth G, et al. Safety and tolerability of cariprazine in the long-term treatment of schizophrenia: results from a 48-week, single-arm, open-label extension study. Psychopharmacology (Berl). (2017) 234:199-209. doi: 10.1007/s00213-016-4450-3

26. Durgam S, Earley W, Li R, Li D, Lu K, Laszlovszky I, et al. Longterm cariprazine treatment for the prevention of relapse in patients with schizophrenia: a randomized, double-blind, placebo-controlled trial. Schizophr Res. (2016) 2-3:264-71. doi: 10.1016/j.schres.2016.06.030

27. Rancans E, Dombi ZB, Mátrai P, Barabaissy A, Sebe B, Skrivele I, et al. The effectiveness and safety of cariprazine in schizophrenia patients with negative symptoms and insufficient effectiveness of previous antipsychotic therapy: an observational study. Int Clin Psychopharmacol. (2021) 36:15461. doi: 10.1097/YIC.0000000000000351

28. Reagila Summary of Product Characteristics [Internet]. Available online at: https://www.ema.europa.eu/en/documents/product-information/reagilaepar-product-information_en.pdf (accessed April 11, 2021).

29. Fagiolini A, Bolognesi S, Goracci A, Crescenzi BB, Cuomo A. Principles of pharmacodynamics and pharmacokinetics in switch between antipsychotics: focus on cariprazine. Riv Psichiatr. (2019) 54(6 Suppl. 1):1-6.

30. Amore M, Aguglia A. Switch to cariprazine in patients with schizophrenia with side effects/medical comorbidities. Riv Psichiatr. (2019) 54(6 Suppl. 1):7-10. 
31. Aubel T. Cariprazine: patients with treatment-resistant schizophrenia. Neuropsychiatr Dis Treat. (2021) 17:2327-32. doi: 10.2147/NDT.S315653

32. De Berardis D, Rapini G, Olivieri L, Giardini A, De Lauretis I, Serroni N, et al. Cariprazine add-on in inadequate clozapine response: a report on two cases. Clin Psychopharmacol Neurosci. (2021) 19:1748. doi: $10.9758 /$ cpn.2021.19.1.174

33. De Berardis D, Vellante F, Silvia F, Gaia B, Di Giannantonio M. Clinical experiences with cariprazine in patients with early psychosis. Evid Based Psyxhiatr Care. (2019) 5(Suppl. 03):15-21.

34. Di Sciascio G, Palumbo C. Experiences of switching to cariprazine. Evid Based Psyxhiatr Care. (2019) 05(Suppl. 03):8-10.

35. Carmassi C, Dell'Oste V, Bertelloni CA, Diadema E, Avella MT, Simoncini $\mathrm{M}$, et al. Clinical experiences with cariprazine in schizophrenic patients with comorbid substance abuse. Evid Based Psyxhiatric Care. (2019) 05(Suppl. 03):11-4.

36. Heck J, Seifert J, Stichtenoth DO, Schroeder C, Groh A, Szycik GR, et al. A case series of serious and unexpected adverse drug reactions under treatment with cariprazine. Clin Case Rep. (2021) 9:e04084. doi: 10.1002/ ccr3.4084

37. Kapulsky L, Brody BD. Urinary retention associated with cariprazine: a case report. Clin Neuropharmacol. (2018) 41:2301. doi: 10.1097/WNF.0000000000000301

38. Mencacci C, Cerveri G, Palazzo C, Gesi C, Salvi V. A clinical case series of switching to cariprazine in schizophrenic patients with partial response to other antipsychotics. Riv Psichiatr. (2019) 54(6 Suppl 1):11-5.

39. Molnar MJ, Jimoh IJ, Zeke H, Palásti Á, Fedor M. Early-onset schizophrenia with predominantly negative symptoms: a case study of a drug-naive female patient treated with Cariprazine. Front Pharmacol. (2020) 11:477. doi: 10.3389/fphar.2020.00477

40. Montes JM, Montes P, Hernández-Huerta D. Cariprazine in three acute patients with schizophrenia: a real-world experience. Neuropsychiatr Dis Treat. (2021) 17:291-6. doi: 10.2147/NDT. S298005

41. Müller HHO, Moeller S. Decline in psychotic symptoms in addition to cardiac and metabolic safety with cariprazine after poor response to previous antipsychotic treatments-a series of two cases. Neuropsychiatr Dis Treat. (2021) 17:1089-93. doi: 10.2147/NDT. S303817

42. Riedesser S, Gahr M. Cariprazine. Nervenheilkunde. (2020) 39:23841. doi: 10.1055/a-0988-2039

43. Vita A, Ceraso A, Valsecchi P. A clinical case series of switching to cariprazine in schizophrenic patients with partial response to other antipsychotics. Riv Psichiatr. (2019) 54(6 Suppl. 1):16-9.

44. Barabássy Á, Sebe B, Acsai K, Laszlovszky I, Szatmári B, Earley WR, et al. Safety and tolerability of cariprazine in patients with schizophrenia: a pooled analysis of eight phase ii/iii studies. Neuropsychiatr Dis Treat. (2021) 17:95770. doi: 10.2147/NDT.S301225

45. Fagiolini A, Brugnoli R, Di Sciascio G, De Filippis S, Maina G. Switching antipsychotic medication to aripiprazole: position paper by a panel of Italian psychiatrists. Expert Opin Pharmacother. (2015) 16:72737. doi: 10.1517/14656566.2015.1013029

46. Sullivan G, Bienroth M, Jones M, Millar H, Ratna L, Taylor D. Practical prescribing with aripiprazole in schizophrenia: Consensus recommendations of a UK multidisciplinary panel. Curr Med Res Opin. (2007) 23:173344. doi: $10.1185 / 030079907 \mathrm{X} 210633$
47. Stahl SM. Cariprazine. Prescriber's Guide: Stahl's Essential Psychopharmacology. 7th ed. Cambridge: Cambridge University Press (2020). p. 137-46. doi: 10.1017/9781108921275

48. van den Heuvel LL. Stahl's Essential Psychopharmacology: Neuroscientific Basis and Practical Applications. 4th ed. Cambridge: Cambridge University Press (2014).

49. Marder S, Fleischhacker WW, Earley W, Lu K, Zhong Y, Németh $G$, et al. Efficacy of cariprazine across symptom domains in patients with acute exacerbation of schizophrenia: Pooled analyses from 3 phase II/III studies. Eur Neuropsychopharmacol. (2019) 29:127-36. doi: 10.1016/j.euroneuro.2018.10.008

50. Taylor DM, Barnes TRE, Young AH. The Maudsley Prescribing Guidelines in Psychiatry. 13th ed. Hoboken, NJ: Wiley-Blackwell (2018). p. 15.

51. Ballon J, Stroup TS. Polypharmacy for schizophrenia. Curr Opin Psychiatry. (2013) 26:208-13. doi: 10.1097/YCO.0b013e32835d9efb

52. Gallego JA, Bonetti J, Zhang J, Kane JM. Prevalence and correlates of antipsychotic polypharmacy: a systematic review and meta-regression of global and regional trends from the 1970s to 2009. Schizophr Res. (2012) 23:125-31. doi: 10.1016/j.schres.2012.03.018

53. Dombi ZB, Barabaissy A, Laszlovszky I, Sebe B, Szatmári B, Németh G. Safety during polypharmacy: a post-hoc analysis examining the safety profile of cariprazine with other antipsychotics in the cross-titration phase. In: 29th European Congress of Psychiatry. Warsaw (2021). Available online at: https:// rgwebsite-prod-media-cdn.azureedge.net/-/media/sites/hq/documents/ areas-of-expertise/scientific-posters/epa-2021_polypharmacy.pdf?rev= e43ef01d0c3e4844ae34334bf198828a (accessed April 11, 2021).

54. Barnes TRE, Paton C. Antipsychotic polypharmacy in schizophrenia: benefits and risks. CNS Drugs. (2011) 25:38399. doi: 10.2165/11587810-000000000-00000

55. Xiao J, Mi W, Li L, Shi Y, Zhang H. High relapse rate and poor medication adherence in the chinese population with schizophrenia: Results from an observational survey in the people's Republic of China. Neuropsychiatr Dis Treat. (2015) 11:1161-7. doi: 10.2147/NDT.S72367

56. Kane JM. Treatment adherence and long-term outcomes. CNS Spectr. (2007) 12:21-6. doi: 10.1017/S1092852900026304

\section{Conflict of Interest: ZD and ÁB are employees of Gedeon Richter Plc.}

The remaining author declares that the research was conducted in the absence of any commercial or financial relationships that could be construed as a potential conflict of interest.

Publisher's Note: All claims expressed in this article are solely those of the authors and do not necessarily represent those of their affiliated organizations, or those of the publisher, the editors and the reviewers. Any product that may be evaluated in this article, or claim that may be made by its manufacturer, is not guaranteed or endorsed by the publisher.

Copyright (c) 2022 Rancans, Dombi and Barabássy. This is an open-access article distributed under the terms of the Creative Commons Attribution License (CC BY). The use, distribution or reproduction in other forums is permitted, provided the original author(s) and the copyright owner(s) are credited and that the original publication in this journal is cited, in accordance with accepted academic practice. No use, distribution or reproduction is permitted which does not comply with these terms. 